Case Report

\title{
Double Interphalangeal Joint Dislocation of the Finger in Adolescent Athletes: A Review of Two Cases and the Relevant Literature
}

\author{
Angelo V. Vasiliadis $\mathbb{D}^{1,2}$ Alexandros Maris, ${ }^{3}$ Maria Tsatlidou, ${ }^{1}$ Edward D. R. Bray, ${ }^{4}$ \\ and Dimitrios Metaxiotis ${ }^{1}$ \\ ${ }^{1}$ 2nd Orthopaedic Department, General Hospital of Thessaloniki "Papageorgiou”, Ring Road-N. Eukarpia, \\ 56403 Thessaloniki, Greece \\ ${ }^{2}$ School of Medicine, Aristotle University of Thessaloniki, University Campus, 54124 Thessaloniki, Greece \\ ${ }^{3}$ Department of Trauma and Orthopaedics, St George's University Hospital, London, UK \\ ${ }^{4}$ Department of Orthopaedics, Great Ormond Street Hospital, London, UK
}

Correspondence should be addressed to Angelo V. Vasiliadis; vasiliadis.av@gmail.com

Received 14 November 2020; Accepted 9 March 2021; Published 15 March 2021

Academic Editor: Da sen Li

Copyright (c) 2021 Angelo V. Vasiliadis et al. This is an open access article distributed under the Creative Commons Attribution License, which permits unrestricted use, distribution, and reproduction in any medium, provided the original work is properly cited.

\begin{abstract}
Double interphalangeal joint dislocation of the same finger is a rare condition. We report two cases of adolescent athletes with distal and proximal interphalangeal joint dislocation. The diagnosis was confirmed with plain radiograph, while anatomical reduction was easily obtained with gentle longitudinal traction. A simple immobilization of the injured finger was applied by buddy taping for two weeks. Early mobilization as tolerated was recommended, and they have made a full return to their previous status of activities within 5 months. We also provide a review of the literature detailing demographic characteristics, cause and mechanism of injury with associated injuries, treatment options, and functional outcomes in this population.
\end{abstract}

\section{Introduction}

Single interphalangeal joint dislocations are common upper extremity dislocations. However, double dislocation of the distal interphalangeal (DIP) and proximal interphalangeal (PIP) joints of the fingers seems to be rare [1]. This type of injury was first reported by Bartels in 1874 [2]. Since then, only case reports have been reported in the literature [3-6]. In this paper, two cases of double dislocation of both DIP and PIP joints in a single finger are reported, alongside with a panorama of the current literature.

\section{Case Report}

2.1. Case 1. A 13-year-old male presented in the emergency department with his little finger of the nondominant hand injured while playing basketball. An axial compression with an excessive hyperextension was applied to the tip of his finger while he tried to steal the ball during the game.

On physical examination, the finger was found to be deformed, swollen and very painful in performing any movement. There were no signs of neurovascular damage or skin lesion. Initial plain radiographs demonstrated a dorsal dislocation of PIP and DIP joints of his little finger in a stepladder deformity (Figure 1). Anatomical reduction was easily obtained with a simple and gentle longitudinal traction. Following reduction, both joints were stable and confirmed on plain radiographs with no apparent any bony avulsion fragment or fracture (Figure 1). After that, buddy taping with the ring finger was applied for two weeks, and the patient was advised to mobilize the PIP and DIP joints as long as the discomfort allowed him.

At 3 weeks of follow-up, the buddy taping was removed, and he had full extension of both joints, with flexion of the 


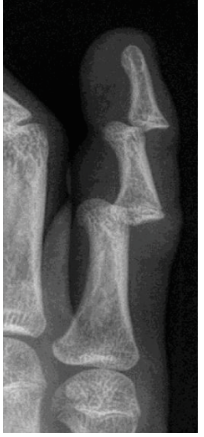

(a)

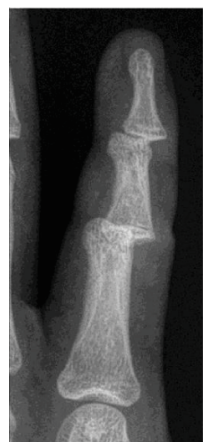

(b)

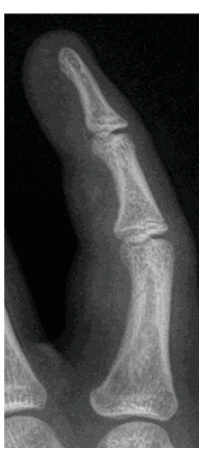

(c)

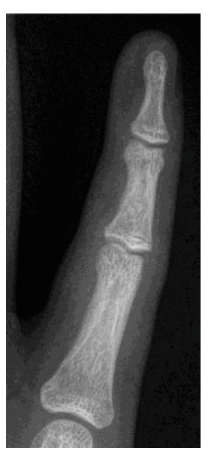

(d)

Figure 1: Anteroposterior and lateral radiographs $(\mathrm{a}, \mathrm{b})$ of the index finger showing dorsal dislocation of both the proximal and distal interphalangeal joints, without any bony avulsion fracture. Postreduction anteroposterior and lateral radiographs (c, d) confirm that all joints are well reduced.

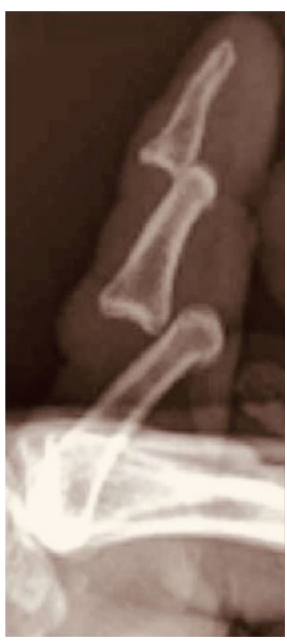

(a)

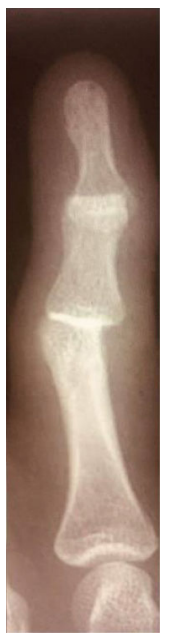

(b)

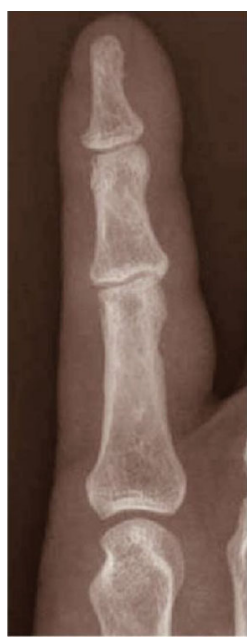

(c)

FIGURE 2: Anteroposterior and lateral radiographs $(\mathrm{a}, \mathrm{b})$ demonstrating dorsal dislocation of both proximal and distal interphalangeal joints, without any bony avulsion fracture. Postreduction radiograph (c) confirms that all joints are well reduced.

DIP joint to $50^{\circ}$ and the PIP joint to $90^{\circ}$. At 6 weeks of followup, the patient had full active range of motion. Within 3 months after the reduction, the patient returned to previous level of musical activities (piano playing) without limitation of motion.

2.2. Case 2. A 16-year-old male sustained a hyperextension injury in his index finger of the dominant had while playing football (goalkeeper). The ball had hit to the tip of his finger while he tried to get the ball away from his goal post.

On physical examination, the finger was markedly deformed with swelling and difficulty on moving the finger. Neurovascular examination was normal. Initial plain radiographs demonstrated a dorsal dislocation of both the distal and proximal interphalangeal joints (Figure 2). Without the use of local anesthesia, reduction of both the dislocations was easily achieved, by longitudinal traction and pressure on the dorsal aspect of the distal phalanx. Plain radiographs confirmed successful reduction without any bony avulsion fracture (Figure 2). Both joints were stable, and the index finger was immobilized with the middle finger for two weeks.
At 3 weeks of follow-up, the flexion of the DIP and PIP joints was $45^{\circ}$ and $75^{\circ}$, respectively, while extension was normal in both joints. At 6 weeks of follow-up, the patient had almost full painless active range of motion. 5 months after reduction, he returned to previous level of sports activities.

\section{Discussion}

Both dislocations of both PIP and DIP joints of a finger is a rare condition. Dislocations of proximal interphalangeal joint of the finger are relatively uncommon due to the protected position of this joint in the hand [2]. While in most of the cases dislocations appear in males, aged near the third decade of their life, our case report highlights two cases of both dislocations of PIP and DIP joints among adolescent athletes (below 16 years of age). The uniqueness is that these are among the youngest cases in the international literature. Sports activities, such as basketball, football, and softball, are by far the commonest cause of injury. Falls is the second common reason implicated in some of the cases, followed by work-related injuries (Table 1) [7-10]. A classic "step- 
TABLE 1: List of publications of dorsal dislocation of the proximal and distal interphalangeal joints of the same finger.

\begin{tabular}{|c|c|c|c|c|c|c|c|c|}
\hline \multirow{2}{*}{ Study } & \multirow{2}{*}{$\begin{array}{l}\mathrm{M} / \mathrm{F}, \\
\text { years }\end{array}$} & \multirow{2}{*}{$\begin{array}{c}\text { Cause of } \\
\text { injury }\end{array}$} & \multirow{2}{*}{ Mechanism } & \multirow{2}{*}{$\begin{array}{l}\text { Finger } \\
(\mathrm{d} / \text { n.d) }\end{array}$} & \multirow{2}{*}{$\begin{array}{c}\text { Associated } \\
\text { injury }\end{array}$} & \multirow{2}{*}{$\mathrm{F} / \mathrm{U}$} & \multicolumn{2}{|c|}{ Outcome } \\
\hline & & & & & & & Extension & Flexion \\
\hline \multirow[t]{2}{*}{ Present study, 2021} & $M, 13$ & Basketball & $\begin{array}{c}\text { Axial compression, } \\
\text { hyperextension }\end{array}$ & $\begin{array}{l}\text { Little } \\
\text { (n.d) }\end{array}$ & No & 3 months & Full & Full \\
\hline & $\mathrm{M}, 16$ & Football & Hyperextension & Index (d) & No & 5 months & Full & Full \\
\hline Clesham et al., 2020 & $M, 23$ & Hurling & $\begin{array}{l}\text { Axial compression, } \\
\text { hyperextension }\end{array}$ & Little $(d)$ & No & 3 weeks & Full & $\begin{array}{c}45^{\circ}(\mathrm{D}), 90^{\circ} \\
(\mathrm{P})\end{array}$ \\
\hline Gorelick et al., 2018 & $M, 41$ & $\begin{array}{l}\text { Personal } \\
\text { training }\end{array}$ & Hyperextension & Little (d) & AFMP & $\mathrm{n} / \mathrm{r}$ & $\mathrm{n} / \mathrm{r}$ & $\mathrm{n} / \mathrm{r}$ \\
\hline Sbai et al., 2017 & $M, 32$ & Bike & Hyperextension & $\begin{array}{l}\text { Middle } \\
\text { (d) }\end{array}$ & No & $\begin{array}{c}6 \\
\text { months }\end{array}$ & Full & Full \\
\hline Abdelaal et al., 2016 & M, 39 & Fall & $\mathrm{n} / \mathrm{r}$ & $\begin{array}{l}\text { Little } \\
(\mathrm{n} / \mathrm{r})\end{array}$ & No & $\begin{array}{c}4 \\
\text { months }\end{array}$ & Full & Full \\
\hline \multirow{2}{*}{ Seki et al., 2014} & $M, 64$ & $\begin{array}{l}\text { Fall from } \\
\text { height }\end{array}$ & Hyperextension & $\begin{array}{l}\text { Little } \\
(\mathrm{n} / \mathrm{r})\end{array}$ & AFMP & $\mathrm{n} / \mathrm{r}$ & $\begin{array}{l}10^{\circ} \mathrm{lag} \\
(\mathrm{P})\end{array}$ & $90^{\circ}(\mathrm{P})$ \\
\hline & M, 66 & $\begin{array}{c}\text { Fall from } \\
\text { height }\end{array}$ & Hyperextension & $\begin{array}{l}\text { Little } \\
(\mathrm{n} / \mathrm{r})\end{array}$ & No & $\mathrm{n} / \mathrm{r}$ & Full & Full \\
\hline Uysal et al., 2014 & $\mathrm{M}, 12$ & Football & Hyperextension & Ring $(\mathrm{n} / \mathrm{r})$ & No & 6 weeks & Full & $\begin{array}{c}75^{\circ}(\mathrm{D}), 90^{\circ} \\
(\mathrm{P})\end{array}$ \\
\hline David-West, 2013 & F, 28 & Fall & Hyperextension & Little (d) & No & 6 months & $\begin{array}{l}15^{\circ} \mathrm{lag} \\
\text { (D) }\end{array}$ & Full \\
\hline Nusem and Loch, 2012 & $\mathrm{M}, 14$ & Rugby & $\mathrm{n} / \mathrm{r}$ & $\begin{array}{l}\text { Little } \\
(\mathrm{n} / \mathrm{r})\end{array}$ & No & 6 weeks & Full & Full \\
\hline \multirow{5}{*}{ Kim et al., 2009} & $M, 23$ & Football & $\mathrm{n} / \mathrm{r}$ & $\begin{array}{l}\text { Little } \\
(\mathrm{n} / \mathrm{r})\end{array}$ & No & $\begin{array}{c}16 \\
\text { months }\end{array}$ & Full & Full \\
\hline & $M, 59$ & Working & $\mathrm{n} / \mathrm{r}$ & $\begin{array}{l}\text { Little } \\
(\mathrm{n} / \mathrm{r})\end{array}$ & AFMP & $\begin{array}{c}12 \\
\text { months }\end{array}$ & $\begin{array}{l}10^{\circ} \mathrm{lag} \\
(\mathrm{P})\end{array}$ & $\begin{array}{c}50^{\circ}(\mathrm{D}), 80^{\circ} \\
(\mathrm{P})\end{array}$ \\
\hline & $M, 43$ & $\begin{array}{l}\text { Fall from } \\
\text { height }\end{array}$ & $\mathrm{n} / \mathrm{r}$ & $\begin{array}{l}\text { Little } \\
(\mathrm{n} / \mathrm{r})\end{array}$ & No & 6 months & $\begin{array}{l}10^{\circ} \text { lag } \\
(\mathrm{P})\end{array}$ & $90^{\circ}(\mathrm{P})$ \\
\hline & $M, 55$ & Working & $\mathrm{n} / \mathrm{r}$ & $\begin{array}{l}\text { Little } \\
(\mathrm{n} / \mathrm{r})\end{array}$ & No & $\begin{array}{c}15 \\
\text { months }\end{array}$ & Full & Full \\
\hline & $M, 21$ & Basketball & $\mathrm{n} / \mathrm{r}$ & $\begin{array}{l}\text { Little } \\
(\mathrm{n} / \mathrm{r})\end{array}$ & AFMP & $\begin{array}{c}14 \\
\text { months }\end{array}$ & $\begin{array}{c}10^{\circ} \mathrm{lag} \\
(\mathrm{P})\end{array}$ & $90^{\circ}(\mathrm{P})$ \\
\hline Kalakoti, 2007 & $M, 45$ & Fall & Hyperextension & Little (d) & No & 18 weeks & $\begin{array}{l}10^{\circ} \text { lag } \\
(\mathrm{P})\end{array}$ & Full \\
\hline $\begin{array}{l}\text { Van Ransbeeck and De } \\
\text { Smet, } 2004\end{array}$ & M, 29 & Football & Hyperextension & $\operatorname{Ring}(\mathrm{n} / \mathrm{r})$ & No & 6 months & $\begin{array}{l}20^{\circ} \text { lag } \\
(\mathrm{P})\end{array}$ & $\begin{array}{c}45^{\circ}(\mathrm{D}), 85^{\circ} \\
(\mathrm{P})\end{array}$ \\
\hline Mesmar, 2000 & $M, 23$ & Basketball & Hyperextension & $\begin{array}{l}\text { Little } \\
(\mathrm{n} / \mathrm{r})\end{array}$ & No & 3 weeks & Full & Full \\
\hline \multirow{3}{*}{ Takami et al., 2000} & M, 35 & Softball & $\mathrm{n} / \mathrm{r}$ & $\operatorname{Ring}(\mathrm{n} / \mathrm{r})$ & No & 3 months & Full & Full \\
\hline & $\mathrm{M}, 53$ & Softball & $\mathrm{n} / \mathrm{r}$ & $\begin{array}{c}\text { Index } \\
(\mathrm{n} / \mathrm{r})\end{array}$ & AFMP & 6 months & Full & $\begin{array}{c}55^{\circ}(\mathrm{D}), 95^{\circ} \\
(\mathrm{P})\end{array}$ \\
\hline & $M, 26$ & Basketball & $\mathrm{n} / \mathrm{r}$ & $\begin{array}{l}\text { Little } \\
(\mathrm{n} / \mathrm{r})\end{array}$ & No & 4 months & Full & Full \\
\hline
\end{tabular}

M: male; F: female; d: dominant; n.d: nondominant, F/U: follow-up; AFMP: avulsion fracture of middle phalanx; D: distal; P: proximal.

ladder" deformity of the affected finger will be obvious, and the diagnosis confirmed with a plain radiograph [3]. The little finger of the dominant hand is the most common digit involved, followed by the ring finger (Table 1). The increased mobility, the lack of protection from the surrounding fingers, and the weakness of the articular capsule and collateral liga- ments of the interphalangeal joints may be posed as logical explanations [2].

All the information gained about the mechanism of this injury is related to be a traumatic hyperextension $[10,11]$. Firstly, an axial compression force to the tip of the finger results in an excessive hyperextension at the DIP joint, 
causing injury of the volar articular capsule and allowing dorsal dislocation of the DIP joint. Subsequently, this force was transmitted to the middle phalanx, which resulted in similar injury of the volar articular capsule of the PIP joint causing a second dorsal dislocation at the proximal joint $[3,8]$. Thus, it is obvious that it is not a "simultaneous" dislocation, but two separate actions that occur in a quick succession and result to this double dislocation of both distal and proximal joints. Also, this type of injury may be accompanied with avulsion fracture of the volar side of the base middle phalanx [10, 12] and rupture of the central slip of the extensor tendon [5]. In our cases, there were not any accompanying avulsion fractures or tendon injuries.

In most dislocations, closed reduction is the treatment of choice if there is not interposition of periarticular soft tissues that prohibits this action and can be easily achieved by longitudinal traction and pressure on the dislocated base of the phalanx, with $[2,6,13]$ or without anesthesia $[4,8]$. However, patients with neglected injuries, open dislocations, ligamentous injuries, and associated fractures or flexor tendon injuries were not so fortunate, especially in cases where larger defects involving more than $50 \%$ of the articular surface may have worse outcomes after conservative treatment and may be better treated with fragment surgical fixation in order to stabilize the joint and avoid limitations of the range of motion $[9,10]$. Static stabilizers, such as collateral ligaments, are the main stabilizers of the DIP and PIP joints. Its attachment in the middle phalanx is crucial to the stability of the PIP joint. Surgical repair is proposed by some authors if an injury of the collateral ligaments, capsule, and/or volar plate are present, in order to prevent later instability of the joint $[6,8,9]$.

As recommended by the majority of the authors, the appropriate treatment after a successful reduction without accompanied avulsion fractures and joint instability is to immobilize the finger in an intrinsic plus position with a splint $[2,3,10,12]$ or to immobilize the injured finger with the correct adjacent finger for support (e.g., little finger with ring finger, middle finger with index finger) and mobilization as tolerated $[1,7,11,13]$. Most authors agree that a period of immobilization between 2 and 3 weeks is sufficient and beneficial, in order to protect the healing process and parallel prevent joint stiffness $[1,2,10,12]$. As a result, early mobilization is recommended, since it helps to minimize immobility-associated complications, and it is also important for a good functional outcome.

\section{Conclusion}

Double interphalangeal joint dislocation in a single finger is rare. In uncomplicated cases, closed reduction is the treatment of choice, and simple longitudinal traction is mostly sufficient. A buddy taping followed by early mobilization usually leads to excellent functional outcomes.

\section{Conflicts of Interest}

The authors declare that they have no conflicts of interest.

\section{References}

[1] K. Clesham, R. P. Piggott, and E. Sheehan, "High-energy traumatic proximal and distal interphalangeal joint dislocation in the same finger," BMJ Case Reports, vol. 13, no. 6, article e235426, 2020.

[2] H. Van Ransbeeck and L. De Smet, "Double dislocation of both interphalangeal joints in the finger. Case report and literature review," Acta Orthopaedica Belgica, vol. 70, no. 1, pp. $72-$ 75, 2004.

[3] M. A. Uysal, S. Akcay, and K. Ozturk, "Simultaneous double interphalangeal joints dislocation in a finger in a teenager," Journal of Clinical Orthopaedics and Trauma, vol. 5, no. 2, pp. 107-109, 2014.

[4] Y. Seki, "Simultaneous double dislocation of the interphalangeal joint of the same finger: a report of two cases," The Pan African Medical Journal, vol. 19, p. 400, 2014.

[5] K. S. David-West, "Double dislocation of distal interphalangeal (DIP) and proximal interphalangeal (PIP) joints of the little finger," Journal of Trauma \& Treatment, vol. 2, no. 2, article 1000163, 2013.

[6] M. A. Mesmar, "Double dislocation of the interphalangeal joints in the finger," Saudi Medical Journal, vol. 21, no. 5, pp. 493-494, 2000.

[7] A. Abdelaal, T. Edwards, and S. Anand, "Simultaneous dislocation of both the proximal and distal interphalangeal joints of a little finger," BMJ Case Reports, vol. 2016, 2016.

[8] H. Takami, S. Takahashi, and M. Ando, "Simultaneous double interphalangeal dislocation in one finger," Archives of Orthopaedic and Trauma Surgery, vol. 120, no. 5-6, pp. 361-362, 2000.

[9] Y. S. Kim, H. S. Song, H. M. Kim, E. Chung, and I. J. Park, "Simultaneous double dislocation of the interphalangeal joint in a finger," Archives of Orthopaedic and Trauma Surgery, vol. 129, no. 10, pp. 1387-1390, 2009.

[10] M. A. Sbai, H. Rejeb, M. El Mchirgui et al., "Simultaneous dorsal dislocation of the proximal and distal interphalangeal joints in the middle finger: a case report," Shafa Orthopedic Journal, vol. 4, no. 3, article e10450, 2017.

[11] I. Nusem and A. Loch, "Simultaneous double interphalangeal joints dislocation in a finger in a teenager," Malaysian Orthopaedic Journal, vol. 6, no. 1, pp. 46-48, 2012.

[12] L. Gorelick, A. Saab, and A. Rozano-Gorelick, "Roentgenologic broken edge "stairway sign" to describe a step-ladder deformity of the finger due to dislocation of the interphalangeal joints same finger: case report and literature review," Archives of Radiology, vol. 1, no. 1, pp. 25-27, 2018.

[13] R. R. Kalakoti and P. Monga, "Double dislocation of little finger in nonathletic person," The Journal of Trauma, vol. 62, no. 3, p. 786, 2007. 